\title{
TEACHERS IN A DISADVANTAGED POSITION ${ }^{3}$
}

Authors:

Adrienn Oravecz

Eszterházy Károly University

Csilla Noémi Borsodi

Eszterházy Károly University

E-mail address of the first author:

ora_adri@msn.com
Lectors:

\author{
Mária Dávid \\ Eszterházy Károly University \\ Magdolna Estefánné Varga \\ Eszterházy Károly University \\ Ferenc Mező \\ Eszterházy Károly University \\ Edina Szabó \\ University of Debrecen
}

Oravecz, Adrienn and Borsodi, Csilla Noémi (2017): Teachers in a disadvantaged position. Különleges Bánásmód, III. évf. 2017/1. szám, 39-50. DOI 10.18458/KB.2017.1.39

\begin{abstract}
The writers of this study will use the expression 'disadvantaged' in a broader sense. The first part of the study deals with teachers and teacher trainees who are in a disadvantaged position because they have got a physical disability. Structured interviews were made with 8 persons. The interviews focused on their educational experiences and also their experiences on the labour market. The key question of the interviews was whether the interviewees had experienced negative discrimination or not. The other part of the study written by Noémi Csilla Borsodi deals with teachers who are in a disadvantaged position because they are working in a vocational school. Many times, a lot of people have written about pedagogical success, about its determination and the grouping of its indicators. First, pedagogical success will be discussed from a different perspective, then the working conditions at a vocational school will be mentioned. Furthermore, the reasons for why the traditional concept cannot be 'substitute' into the 'equation of success' for vocational school. Finally some of good practises will be shown that could help motivating students.
\end{abstract}

Keywords: Teachers with disability, being a vocational school teacher of 'general subject as a 'disadvantaged' position, definitions of pedagogical success, drop-out

Disciplines: pedagogy

\footnotetext{
3 The editorial board does not take any responsibilty for the English of the papers. Indeed, we made some slight changes but wanted to keep the style of the authors.
} 


\section{Absztrakt}

Ebben a tanulmányban a szerzők tágan értelmezik a hátrányos helyzetet. A tanulmány első része olyan tanárokkal és tanárjelöltekkel foglalkozik akik fogyatékosságuk miatt hátrányos helyzetüek. A kutatás során 8 strukturális interjú készült. Az interjúk kulcskérdése az volt, hogy az alanyok részesültek-e negatív diszkriminációban az oktatás és a munka világában. A tanulmány második része a szakiskolai tanárokkal foglalkozik. A pedagógiai siker értelmezése új nézőpontból lesz bemutatva, továbbá annak okait tárgyalja a szerző, hogy a hagyományos siker értelmezés miért nem illik a szakiskolai környezetbe. Végül néhány a szakiskolában használt jó gyakorlat kerül bemutatásra.

Kulcsszavak: Fogyatékkal élő tanárok, Szakiskolai közismereti tanárok, Pedagógiai siker, Kiégés

Diszciplína: pedagógia

\section{PART: TEACHERS WITH DISABILITIES}

\section{Introduction}

Social inclusion of people with disabilities is a re-current topic especially since Hungary belongs to the European Union. Several research were made about attitudes towards people with disabilities including the research titled Opportunities for social integration among young adults living with disabilities in contemporary Hungary in this project the goal was to map the status and positions of youngsters and young adults in higher education, as well as the current weight, prospects, and long-term participation in academic life and the labour market of the target group's representatives. The project's researchers also wanted to find out their motivation why they wanted to take part in higher education. The first major part of the research focused on the actual knowledge of students in the institutions of higher education about disabilities in general as well as opportunities of social integration of people living with disabilities and what can be done to help them. The second part dealt with bodies and organizations in the labour market who can help people with disabilities to find job or create working conditions which are suitable for their special needs (Laki, 2010). Another interesting scientific research examined parents' attitude towards children with cerebral palsy. According to the writer's opinion parents are the most important factors in inclusive education (Zsebe, 2013). The third article titled as Integration Experiences of The Petö Institute which Operates in Segregation. In the article they followed their students' integration into normal basic, secondary and higher education from 2000 until 2010. The results were very positive. (Feketéné and Pásztorné, 2010).

What makes this research unique is that it directly address to people who lives with disabilities. Former students of The Petö Institute were involved into the research who works as a teacher but in order to find more representatives of the target population the snowball sampling was used. The qualitative research method more specifically structured interviews had been applied for data collection.

\section{Two different understanding of disability and the history of qualification for disabled people}

According to the first understanding people with disabilities negatively differ physically or mentally from their able-bodied peers. These differences can be measured by medical or psychological tests. The other understanding focuses on the organisational and institutional tasks which makes inclusive education possible. (Bánfalvy, 2008.) After the two different approach to disability the writer will talk about briefly the history of qualification for people 
with disabilities. Until the $19^{\text {th }}$ century the need of qualification for disabled persons had not been appeared. It was after the French Revolution when they were registered and slowly but surely special institutions were opened. In the developed countries including Hungary segregated schools started to operate, for example the school for blinds. In the $20^{\text {th }}$ century the services of special education became more and more developed. People with disabilities received treatment and rehabilitation which was best suitable for the severity of their disability. The present trend in the European Educational Policy wants to foster social integration of people with disabilities through education. The differences can be found how different European countries define and think about inclusive education. The integration movement began in the Scandinavian region with the Principle of Normalization. In Denmark in 1969 it was defined that if not necessary children with disabilities should learn with their able-bodied peers. Then in 1975 in the USA it was enacted that the environmental barriers must be reduced and they had to learn in the mainstream education and not in segregation. This law also supported parents' rights and the introduction of various pedagogical examination and tests including annual development report about their health condition. At the end of the century three tendencies were general in the practice of integrated education. In the first tendency integration exist as an exclusive solution, for instance in Italy. The Italian law was enacted in 1977. The second type of tendency the permissive liberalism was typical of England. The English Educational Law in 1981 became known as 'Special Needs in Education' later this was further modified in 1993. It was defined in this law in order to find the best education for the children must gather as many information as possible from different specialists. Proper control and occasions for regular consultation provided by The School of Special Education. The task of the segregated school was to prepare the children for inclusive and mainstream education both physically and psychically. The third tendency was called regulation based on practise and this was usual in Germany. The parents took part very actively and fight for their children rights. The Movements of The Parents quickly spread through the country and had a representation in each region. For example, the Integration Law of Hessen Region (1992) emphasized that basic education must provide inclusive education if the parents claimed for it. The third paragraph of the law dealt with the supportive and consultative role of primary schools. Wrote about two different learning management. The first type of learning management when the special education teacher worked with students during the lesson. The second type when the primary school teacher did the process of development herself based on the recommendation of the special education teacher (Deák, 2007).

\section{The Situation and the Process of Integration in Hungary}

The first law in connection with integration was written into The Constitution of The Hungarian Republic in 1949. In 1998 The Hungarian Republic joined to The New York Agreement which defined the rights of the children. The next important law appeared in 1993. This educational law created the theoretically background for integration. The next important law was introduced in 1998. XXVI. Law declared fair treatment and equal rights for people with disabilities (Vargáné Mező, 2006). In the last 30 years children with special educational needs had been played a very significant role in the educational policy of OECD. In 2006 The UN resolution clearly emphasized active social presence of people with disabilities and called the attention to the importance of information and data collection. The Pedagogical Professional Group of Children with Special Needs was founded in 2007 (Csányi,2008). Due to the favourable international and national terms and laws more and more people with disabilities can participate in the normal education. The 1. table shows the number of students who took part in integrated education from nursery school till secondary school. 
1.table: The number of students who took part in integrated education (resource: Csányi, 2008.)

\begin{tabular}{|l|l|l|}
\hline School years & Frequency(student) & Relative frequency* \\
\hline $2002 / 2003$ & 18165 & $28,3 \%$ \\
\hline $2003 / 2004$ & 24993 & $36 \%$ \\
\hline $2006 / 2007$ & 41978 & $51,4 \%$ \\
\hline \multicolumn{2}{|c|}{$* 100 \%=$ total number of students of a school year }
\end{tabular}

Similar survey was done by the after care service of the Petö Institute in $2008-2009.55 \%$ of the former students took part in integrated education. 14\% was nursery school students $21 \%$ was primary school students $12 \%$ was secondary school students $6 \%$ of them took part in higher education (Feketéné and Pásztorné, 2010). Though the results are very positive year by year but in the real daily education rigid integration is still in practise due to the lack of personal and technical terms.

\section{The research sample}

8 structured interviews were made with disabled teachers. The sample involved four men and four women. The distribution of their age were the following: three of them were between 20-30 years old, four of them were 30-40 years old and, only one person was between 50-60 years old. The great majority was born with cerebral palsy. Two people from the eight was born with visually impairment. Only one person was born with auditory impairment.

In the interviews the writer was eager to know if they took part in integrated education or not. The great majority took part in integrated education. The results correlated with the statistics mentioned above. Only two person took part in segregated education during their nursery school years. Only one of them learnt in segregation during his secondary school years. The majority said that he/ she was fairly treated and accepted by his/her classmates. It was said by H. B that she could make very close friendships during her secondary school years and up to the present day she keeps in touch with them.

The minority for example H. R. said she studied at The Institution for Blinds from the $1^{\text {st }}$ grade until $4^{\text {th }}$ grade, then she was sent to a normal primary school where she was looked down on by the others therefore she had to change school. She said the following: "While I was studying in The Institution for Blinds I was in a protective environment but in the normal primary school I was the black sheep of the class. I was unprotected and I had to find my own position in the race condition and try to keep up with the others.” M. G. also said his primary school years were very difficult. He was taunting constantly, but soon he learnt not to pay attention to these mockery words.

In the second part of the interviews examined the reasons for their career choice. Two person from the sample said he /she wanted to be a teacher because his/ her former teacher. G. J. said that he had a very good history teacher and he was greatly influenced by her. H. B. also mentioned her history teacher as a great model. After her first history class she went home and said the following to her parents: "Mummy, Daddy I want to be an archaeologist when I grow up. Later the picture became clear and I chose the faculty of history at university but I still have very vivid memories of my history teacher." Personal interest was the other reason. Gy. D. said he enjoyed drawing since his childhood. He went to private drawing classes to develop his talent. As an adult he wanted to be an artist, but soon he recognised that he will not earn enough money for living so he decided to get a qualification as a drawing teacher. $\mathrm{K}$. B. told she could not decide between psychology and teaching Hungarian as foreign language as result she is now doing both academic specialization, but she added she was always interested in teaching Hungarian language for not a native speaker because it is more challenging. Two people said their disability determined their career orientation. All of them 
said that their teaching practicum at the university was a positive experience. K. B. mentioned that the students were kind and helpful. Her blindness was not seen as a problem, rather the students enjoyed that they were allowed to shout instead of rising their hands up during the lesson. After they had completed their teaching practicum successfully the majority felt that it was the best decision to take when they applied for teacher training.

The third part focused on their experiences on the labour market. The great majority said they were not discriminated because of their disability. Moreover, two of them got a job soon after graduation due to his acquaintanceship. The minority of the research rather represents the current situation in Hungary. M. G. said when he applied for a job he often experienced negative discrimination for example the employer shut the door in front of him or his job application was refused due to his disability. R. G. said it took more than two years to find his present job. Before that he was employed by a charity for blind people. He had been fired during his convalescence after his leg operation. He had hard times because he had to cope with the physical pain but also the psychical pain of being unemployed. His negative experiences continued when he worked as a hotel receptionist. The hotel employed people with disabilities. As R. G. said they did it because they wanted to get a huge amount of financial support from the Hungarian State. Money talked instead of good intention. The author hopes that the reader will be deep in though after reading these shocking examples.

\section{Final thoughts and conclusion}

As the author experienced for people with disabilities the success has a greater importance in life because they have to demonstrate day after day that they are as valuable as able-bodied people. Education is one of the fields in which they can have a real sense of achievement. As the disabled teachers noted that for them pedagogical success means when they see their students are more tolerant and helpful with people who are in the disadvantaged position. The disabled teachers mentioned that they find it important to enhance the students' emphatic skills during form class activities. The writer strongly believes they have a significant role in the formation of mind and attitudes of the next generation. Thanks to the pedagogical work of teachers with disabilities maybe a new and more tolerant young generation will grow up and social exclusion will not be as harsh as today.

\section{PART: SITUATION OF VOCATIONAL TEACHERS}

\section{The pedagogical success in general}

Although the definition of success is relative, yet to be able to write about its implications at a vocational training school, it is essential to broadly outline what a teacher's success means 'in general'. Beatrix Füzi identified three indicators: good results by the students, popularity among students, and the good general mood of the teacher (Füzi, 2007; 2012; 2013). According to another research, the productivity of an educator coincides with his or her 'popularity', and it mostly depends on how much he/she can win the student's sympathy. (Suplicz, 2011). These works emphasize that although the teacher's methods are secondary, and are hard to correct them afterwards, once the students 'have categorized' them (Füzi 2013), a sort of 'ranking', an order of popularity can still be established among them. The teachers and teacher candidates like the student presentations as a form of work. This is the most effective way for them to help the realization of student performance, the development of communication skills, and demonstrably the students also like this interactive form of performance, as they also gladly act as 'junior teachers' during group work. (Füzi, 2012; Mrs. Kovács Duró, 2004; K. Nagy, 2006) It is proven to be the biggest disadvantage, if the teacher's personality is not what's desirable. (This picture is toned further by the fact that getting to know someone is a fairly complex process, and the students might only see the 
current general mood of the teacher role personality.) Another important factor is the level of appreciation for the specific teacher's subject among the colleagues and their students. The good teachers like their subjects and consider them important, whereas the bad teachers don't feel that way as much. It is certain in any case that the series of failures sooner or later reproduce themselves, the teacher will work without motivation, thus he/she won't be able to motivate the students either (Suplicz, 2011).

\section{The society of vocational school students - the risks of failures at school}

Many researchers consider the vocational school to be the 'home' of failures, where the students who attend experienced failures at their previous schools (Bánfalvy, 2001), or they are the children of poor parents with low level of education (Mogyorósi, 2009). A vocational school is the scene of student heterogeneity. These learning communities are 'considered to be a collecting class' by some teachers, who also believe that their development is didactically unachievable. This is primarily characteristic to the older generations, but the younger ones do not yet possess the necessary diagnostic skills, it is harder for them to determine 'at a glance' who those students are that 'they have to watch closely' (Óhidy, 2013).

On heterogeneity we do not just mean the diversity with respect to abilities, but also with respect to age groups, namely that here the 16 year old youngsters go to the same class as the 24 year old full-time students. Many students enter the school with a secondary school leaving examination certificate or after finishing the 10th grade, as an adult student for whom compulsory schooling doesn't apply. In fact many of them 'end up' at this 'less prestigious' school - not offering a secondary school leaving examination certificate - because of their relative failures, while others having obtained the secondary school leaving examination certificate, but without a qualification, do not feel ready to start a vocational training that requires a secondary school leaving examination, or to enter higher education. They all lived through failures, but as the learning community itself, the failures are also quite heterogeneous. For some failure means the bad grades that they got in their previous schools, while for others it means not passing a class. The main failure for a student and teacher at a vocational school is 'dropping out', whatever we mean by that. The term itself covers a different meaning country by country. In Hungary we don't primarily mean not passing, it rather means that the student is gradually missing school more and more often due to lack of motivation, possibly truancy, or other reasons. In countries, where the expansion of secondary education has not yet happened, e.g. Portugal, neither dropping out nor repeating the school year is a general problem (Szöke, 2009). The OECD statistics examines two kinds of dropping out; one is the number of youngsters aged 16-19 who do not participate either in the education or at the labor market, the other is the ratio of 20-24 year olds, who do not have secondary education. Although in our country the rate of dropping out significantly decreased before the regime change, it showed an increase again after 1995, namely, the assessment carried out among the 18-24 year olds proved that the $12 \%$ of these youngsters don't have any qualification. This problem is also specific to vocational training schools, as in the high schools and vocational secondary schools this issue is only the individual tragedy of a few percent of the students, while in relation to the vocational training schools this is a social phenomenon, since it effects a third of the youngsters (Szőke, 2009). Educating dropouts together with students who have detrimental situations is the main task of a vocational training school. Due to the character of the continuously changing vocational training at these schools, these students can amount for two third of the class (Mogyorósi, 2009). Therefore they have to be considered as a majority, and not as an exclusive educational specimen. The teacher must find a different role as an educator. He or she cannot live the role of the 'lone' 
teacher, but has to become a 'team player'. Not only the teacher has to become able to cooperate with the student community, but with his or her colleagues as well (Nagy, 2009).

\section{An empirical research}

We wanted to see if we can more or less generally state that the sense of success for a teacher working in the vocational training changes in a special direction, and whether we can consider a teacher successful who can merely hope that the students attend her classes, feel themselves comfortable, and appreciate her. Our hypothesis was based - after consulting the literature - on this. We assumed that the general knowledge teachers at the vocational training schools consider motivating the students and preventing them from dropping out as their main success. We thought that the students consider - unlike the teachers - organization less important than the class being entertaining. We hypothesized that the teachers consider the unpredictable student attendance and the heterogeneity to be the most serious problems at the vocational training school. We believed that the vocational training school students attend the classes of those teachers who they like. Dropping out was considered as the common failure of the vocational training teachers, the forewarning signs of which are interpreted as a danger even by the students.

Our goal was to identify the student and teacher signals relevant to the problems that are characteristic to vocational schools. 18 colleagues responded to the questions. Two of them are from Nógrád county, 4 people work in Miskolc, one person is the employee of a vocational training institution in Nyíregyháza, the others all work at schools in Budapest. In terms of their subjects, they 'make up a heterogeneous group'. General knowledge and technical teachers, or learning methodology specialists can all be found among them. The students we questioned are from Miskolc. Because of the unpredictable student attendance and the heterogeneity regarding their abilities, 5 ninth grader, 12 tenth grader, and 14 eleventh grader filled out the questionnaire. The research is by no means representative, however both the teacher and the student responses clearly outline how they conceive their own successes, effectiveness, and the main obstacles to their work. In the next section of our work we present the results of this mini research, before we would outline the results of our inquiry among the students.

\section{Presenting the results of the teacher assessment}

While questioning the colleagues, we learned that most of them identified the lesson planning difficulties caused by external factors as the main problem that are hindering the efficiency of their work. They could evaluate the weight of the individual problems on a scale of 5 (problems with a vision for the area to teach; lesson planning difficulties caused by external factors; problems with methodology; discipline issues). This obstacle related to learning and teaching organization received 4.3 points, which can be viewed as completely evident, a "necessary bad", due to the lack of material assets and the lack of student leaning items, which are natural in vocational training. These difficulties are followed by the methodology obstacles with 4 points, after which the lack of vision for the area to teach is listed with a value that is a mere 9 hundredth smaller. Perhaps the weight of this problem did not appear with such intensity as it had been assumed, because we equally questioned colleagues teaching technical subjects and general subjects, not exclusively the colleagues teaching 'the lacking general knowledge subjects' (natural studies, social studies, communication-Hungarian), who are trying to support and motivate students virtually without any teaching tools, or more precisely, with the teaching tools they had made themselves.

The colleagues who were questioned consider tolerance to be the most essential from the aspect of teacher effectiveness. (On a scale of 5, this factor received 4.72 points, which can be viewed as outstandingly high.) In a very 'tight list', that is with almost identical order of 
importance, this is followed by efficient communication with the students (with a score of 4.58), and empathy (4.54), as well as the commitment to lifelong development (4.58), from which the methodological diversity also isn't far with its 4.5 points.

We were interested to see the consequences of separating the tolerance that is connected to the acceptance of being different from the empathy that is related to a sense of sameness, whether there is a correlation between the two values. The efficient communication with the students based on these is of key importance, as is the cooperation with them (4.45 points). However, for some reason the cooperation with the colleagues does not seem to be of key importance for the colleagues, albeit we assumed that it was fundamental. Another thing that we found strange: the judgment on the sense of humor is rather "medium" (3.2) in the eyes of the teachers.

Among the difficulties specific to vocational training schools, the strong heterogeneity with respect to age and ability (4.5 points) and the unpredictable student attendance (4 points) emerge as the most striking obstacles. We would have also liked to know how well the teachers can judge their own alternative sense of success, but in 5 cases we did not get a response for that part.

From the choices for this question the following dimensions were found: achieving motivation, student development (added pedagogical value), (former is implied by 6 , the latter by 4 responses), providing equal opportunities and substantial implementation of personal example, conveying general literacy and know-how (each in 1 case). If we consider this response to be in the "accomplishing development" category, then we can state that my colleagues bring that to the fore. Furthermore, a response was received that emphasized motivation and cooperation, and one person interpreted the student attending classes as a success. On the basis of all this we can infer that motivation and student development (which cannot be achieved without motivation) are the leading factors that the teacher at a vocational training school pursues. The teachers would like to achieve that these students become more motivated, attend school and thereby develop (in the areas of knowledge, ability, skills, personality, and self-knowledge). In relation to failure we asked multiple choice questions. The colleagues' unambiguous opinion was that dropping out means the real failure (based on 12 responses). 6 people stated that for the teachers a sense of failure can be caused by the students' lack of motivation, 5 thought that this can be caused by not attending classes, and only two of them believed that the students' disorderly conduct, continuous lack of discipline could be a cause. We were surprised that in multiple different groups of questions the response We received stated that the problem with the lack of discipline cannot be considered relevant. Nevertheless, if we think about it, these statements confirm the following: once the vocational school students attend the class, then they like to be there too. If they like the class, they are not disruptive. The trouble is with those who don't even attend. This is what puzzles the teacher, and how he or she could keep those who show up inside, how he or she could be able to influence (through them, establishing intrinsic motivation) the ones not attending. How should he or she give a motivating class (notwithstanding the difficult circumstances due to the unpredictable attendance) the news of which reaches the others and possibly arouse their interest. In this context, it occurred to us that for the conscious realization of all this the colleagues' cooperation is crucial. This view wasn't shared by the interviewees.

In relation to the suppositions about 'good' and 'bad' teachers, we were interested in seeing how the result of our mini research aligns with the information can be read in the literature, and to what extent are the teachers' suppositions confirmed by student opinions. Every single factor that we listed for the "bad teacher", also appeared as a virtue for the 'good teacher'. It was assumed the teachers would think that the students don't (like to) attend the 'bad' teacher's class, therefore it fairly surprised us to see this factor being only the third among the 'bad teacher' criteria, moreover it only received 3.7 points. The 'leading' factor was the black 
pedagogy. Namely, the 'bad' teacher finds pleasure in insulting the students. (4.25 points). The 'good' teacher seems to feel good in the classroom (4.7 points), likes to chat with students (4.6 points), and the methodologically diverse teacher is the one who provides opportunities for student contributions and is not teacher-centered (4.5 points). Basically, the educators said yes to the 'criterion' related to 'being a good teacher' that is also presented in the literature, except for the empathy in this case (3.3 points). This is not surprising: the question was about how the students might conceive the 'good teacher'. Discipline, with 2.9 points, seems to be the least essential 'virtue'. In order to get a clearer picture, we questioned the students as well, in connection with the same categories as for the teachers. We were interested in seeing what they consider the most essential 'virtues' for the teacher. Do these match the teachers' own set of values that are based on their pedagogical experience, specialized knowledge, and professional literacy?

\section{Presenting and evaluating the results of the student responses}

All of our interviewed students are youngsters who attend a vocational training school in Miskolc; they are in the 9th, 10th, and 11th grade. They were randomly chosen, and only those students could be in the sample who came to school at that time. They are members of a heterogeneous student group, many of them struggling with basic reading comprehension and written composition problems, especially among the 9th graders, therefore we did not ask them textual, i.e. open-ended questions in my questionnaire. Subsequently, in the form of individual interviews, then as a group interview, we uncovered the shortcomings among them as well. The students' responses evince the following: although they did not designate planning as the most essential teacher competency, it clearly turned out that they consider those shortcomings to be the most serious that demonstrate lack of planning. The illogical reasoning (3.76 points) and the lack of methodological diversity (also 3.76 points) are these characteristics. These characteristics became 'top three', but none of the teacher deficiencies received a score above 4 , thus even the 'most serious' problems have at most medium significance in the eyes of the students we questioned.

For them, the teacher's 'lack of knowledge' is one of the least significant issues (3.1 points). Only the lack of discipline seems to be less disturbing than this, although in case of a more representative sample of students this difference could have disappeared, or even reversed (3 points). Later on, after filling out the questionnaire, several students orally confirmed their suppositions about the lack of knowledge. Their reaction was something like this: 'There is no such dumb teacher who would not be able to give a class.' For them the 'good teacher' primarily is the one who can clearly explain his or her specialized subject and who helps them understand the relationships between the subjects (4.4 points), as well as the teacher who gives entertaining classes (4.2 points). The students consider those teachers bad who insult their students (4 points). All the other bad teacher characteristics lag behind this one. Perhaps being late (3.8 points) can also be considered noteworthy in their case.

\section{SUMMARY OF OUR RESULTS}

Both the teachers and the vocational school students consider the effectiveness of the teacher-student communication and the underlying organization to be the most essential duty for the teacher. Motivation and working in a good atmosphere have key roles. The students must experience a sense of achievement, and the teacher can make this possible with methodological diversity and logical reasoning. The heterogeneous group composition and the unpredictable student attendance imposes extra planning duties on the teachers, who must fulfill these so that they can lure the students to school. The methodological diversity as the 'underlying factor' of planning has an outstanding role in such institutions as well. Every 
colleague who evaluated the role of planning to at least 4 points, also evaluated the methodological diversity to 4-5 points. The lack of discipline cannot be viewed as a problem, and the students have no desire to be disciplined either. The youngsters who study in a selfregulating way or seeking to do that will attend school even after they reach the age after which schooling is not compulsory. The student who attends school even after reaching this age is motivated. If the student loses motivation, the teacher also feels that to be his or her responsibility and failure, since the loss of motivation and frequent absence is the symptom for the danger of dropping out. All of this is confirmed most definitely by the students' order of values that they create about the 'good teachers'. We seem to discover a sort of relationship between all this, namely the following: it is possible that the 'good teacher' explains his or her specialized subject clearly, and at the same time helps the students understand the relationships between the subject and other subjects, that is he or she gives an interdisciplinary class while considering the students' individual 'paths', he or she is aware of the fact that getting to know the students is the basis for everything. The teacher gives entertaining classes.

During the test of my hypothesis we found that the interviewees consider motivating the students and preventing them from dropping out as the main success. Organization is of key importance for both sides, even if the students consider it as a sort of 'backstage secret'. For the class to be entertaining, to have a logical structure, and the desire of harmonization with other subjects all require planning. The teachers we sought out do indeed consider strong heterogeneity in student composition and the unpredictable student attendance to be the greatest challenges of being in vocational training. The role these play in the planning duties is less relevant. The vocational training school students did not always opine that they do indeed attend the 'good teacher's class'. (Over the course of the interviews they shed light on the'psychology of the absences': there are the 'notorious absentees', and there are those who only seldom miss classes. However, in these cases they 'take the whole day off' and the 'good teacher's' class might also 'become a victim' of the students' 'arbitrary leave of absence'.) The teachers we questioned consider dropping out as a common failure, the forewarning signs of which are interpreted as a danger even by the students, however, they only consider the cooperation between the teachers and students to be important, deeming the teachers' common problem solving irrelevant.

The indicators of success for a teacher who works in vocational training is similar to his or her colleagues' who work at different types of institutions (popularity, teacher's good general mood, student performance), while here student performance means avoiding dropping out, the student's motivation toward getting a profession, and the desire for self-improvement. In this case by 'added pedagogical value' we mean becoming more independent and getting a higher level of educatedness. It could be the topic of further research to see what the reason is for the teachers not considering collaboration with their colleagues as of key importance, and whether this is indeed a 'mass phenomenon'. Let us in the closing section of our study present a few 'good practices' that can help you to 'lure the students to school'.

\section{Some good practices that can help in the motivation of vocational school students}

Initially the author only taught the communication-Hungarian language and literature subject - which was introduced during the 2013-14 school year - in the 9th grade. Her educational activity is characterized by different classes, different demands, and different approaches. At the beginning of this assignment my goal was to develop critical thinking (still is), and to arouse their interest toward my colleague's complex subject named social studies, furthermore to shed light on the fact that there is no truth, merely viewpoints. The path, which is well-tried by now, that lead her here she discovered thanks to an accidental situation. Seh arrived as a substitute. She had just come across a film about Elizabeth Bathory that depicts 
her as a 'blood countess'. There was an opportunity to watch the film, evaluate it according to a list of discussion points, then to implement a reading comprehension practice arguing that the countess was the victim of a kangaroo court. The students were divided by this topic. Later she taught them the techniques of debate and reasoning based on this as well. It served as a starting point for the other contents of the subject, e.g. to introduce the work of Kálmán Mikszáth and the criteria of the folksy style (starting from the novel about Elizabeth Bathory, titled Csejte vára és asszonya [The Lady of Castle Csejte]). This topic had many aspects that we carried forward, e.g. we compared the pact with 'the Devil' made by Goethe's Faust to Elizabeth Bathory's 'bathing in blood'. The people of earlier times did not believe in talent, exceptional gifts, or genetics. Anything that was different from the 'ordinary' they attributed to 'the Devil'. This way of thinking was also tied to the contents of natural studies and social studies. She often does situation exercises with her students, the objective of which can be the practicing of communication styles or the forms of language usage, and the development of problem solving thinking. These games are similar to the board game named 'Beugró', and when she realized this similarity she bought one of these. In addition, she also equipped a Definity game with technical terms for the purpose of practicing foreign words and new concepts. All of these contribute to the good atmosphere of our classes, the students do not distance themselves from frontal work, and more of them like the 'playful' recitations. During grammar classes, to "sweeten up" the assessments she turns to the quizzes at www.kvizpart.hu or www.anyanyelvapolo.hu, or to the previously mentioned Definity game.

\section{REFERENCES}

Bánfalvy, Cs (2001). Szakképzés a szakképzés föáramán kívül. Educatio, 2, 278-294.

Bánfalvy, Cs. (2008). A mai integrációs folyamatok és azok előzményei. In Cs. Bánfalvy (ed.). Az Integrációs Cunami. Tanulmányok a fogyatékos emberek iskolai és társadalmi integrációjáról (Vol. 1. pp.11-44) Budapest. ELTE Eötvös Kiadó

Csányi, Y.(2008). Új utak és törekvések az SNI-tanulók oktatása terén. In Cs. Bánfalvy (ed.), $\mathrm{Az}$ Integrációs Cunami. Tanulmányok a fogyatékos emberek iskolai és társadalmi integrációjáról (Vol. I. pp.65-74) Budapest. ELTE Eötvös Kiadó

Deák, A.(2007). Érvek és ellenérvek mozgássérültek integrált nevelésével kapcsolatban Empirikus vizsgálat Spanyolországban és Magyarországon. Doktori Disszertáció. Budapest. Eötvös Lóránt Tudományegyetem

Feketéné, Szabó É. és Pásztorné, Tass I. (2010). Integráció- Egy szegregáltan működő intézmény tapasztalatai. Budapesti Nevelö, 2, 23-38.

Füzi, B. (2007) A sikeres pedagógiai munka néhány összetevője. Egy kísérlet tanulságai. Pedagógusképzés, 3, 9-30.

Füzi, B. (2012) A tanári munka sikeressége a pedagógiai attitűdök, a tanár-diák viszony és az iskolai élmények összefüggésrendszerében. Doktori Disszertáció (kézirat) Budapest. Eötvös Lóránt Tudományegyetem

Füzi, B. (2013) Az érzelmi-kapcsolati elemek tanítási módszerek hatékonyságára gyakorolt hatásai. In. Tamás Kozma - László Perjés (ed.). Új kutatások a neveléstudományokban. A munka és nevelés világa a tudományban. (Vol. 2. pp. 153-169) Budapest. MTA Pedagógiai Tudományos Bizottság, ELTE Eötvös Kiadó

K. Nagy, E. (2005) A társas interakció mint tudásgyarapító tényező a heterogén osztályokban. Iskolakultúra, 5, 16-25.

Kovácsné Duró A. (2004) Tanár szakos egyetemi hallgatók értékelési tudása és kompetenciái. Magyar Pedagógia, 2, 203-224.

Laki, I.(2010). Fogyatékossággal élő fiatal felnőttek társadalmi integrálódásának esélyei és lehetőségei a mai Magyarországon. Budapest. L’Harmattan Kiadó 
Mogyorósi Zs.(2009) A hátrányos helyzet öröksége. In. Mária Nagy (ed.). Tanulmányok a neveléstudomány köréből. A közoktatás méltányossági problémái és a tanárképzés. (Vol. 1, pp. 7-39.) Eger. EKF Líceum Kiadó

Óhidy, A. (2013). Heterogenitás, tanári kompetencia, tanárképzés. A heterogenitás pedagógiájára való felkészítés a német tanárképzésben. In. Tamás Kozma - László Perjés (ed.). Új kutatások a neveléstudományokban. A munka és nevelés világa a tudományban. (Vol. 7, pp. 475-490) Budapest. MTA Pedagógiai Tudományos Bizottság, ELTE Eötvös Kiadó

Suplicz, S. (2011) A tanárok pszichológiai jellemzői diákszemmel. Doktori Disszertáció (kézirat), Debrecen. Debreceni Egyetem

Szőke, K. (2009). A lemorzsolódás problémája. In. Mária Nagy (ed.). Tanulmányok a neveléstudomány köréből. A közoktatás méltányossági problémái és a tanárképzés. (Vol. 1. pp. 41-58.) EKF Líceum Kiadó, Eger

Vargáné, Mező L.(2006).(Download: 2016. 07.06.)

(Web: http.//rs1.szif.hu/ nyeki/okt/jog_hatter.pdf).

Zsebe, A.(2013). Mozgássérült gyerekek inkluzív nevelése. In I. Bábosik (ed.), Az iskola optimalizálásának lehetőségei.(Vol.3, pp. 139-152.) Budapest. Eötvös József Könyvkiadó. 